\title{
Climate-induced landslide reactivation at the edge of the Most Basin (Czech Republic) - progress towards better landslide prediction
}

\author{
J. Burda ${ }^{1,2}$, F. Hartvich ${ }^{2,3}$, J. Valenta ${ }^{3}$, V. Smítka ${ }^{4}$, and J. Rybár ${ }^{3}$ \\ ${ }^{1}$ Brown Coal Research Institute j.s.c., Most, Budovatelů 2830, Czech Republic \\ ${ }^{2}$ Faculty of Science, Charles University in Prague, Albertov 6, Prague 2, Czech Republic \\ ${ }^{3}$ Institute of Rock Structure and Mechanics, Academy of Sciences of the Czech Republic, Prague 2, Czech Republic \\ ${ }^{4}$ Department of Special Geodesy, Faculty of Civil Engineering, Czech Technical University in Prague, Czech Republic
}

Correspondence to: J. Burda (burda.geo@gmail.com)

Received: 4 June 2012 - Published in Nat. Hazards Earth Syst. Sci. Discuss.: -

Revised: 10 December 2012 - Accepted: 23 December 2012 - Published: 15 February 2013

\begin{abstract}
The catastrophic landslide at Eisenberg in North Bohemia was reactivated during January 2011. This study integrates a range of geoscientific evidence in order to constrain the spatial and temporal development of this reactivation. It has investigated long-term geodetic measurements to assess the morphological development of the site over the last two decades. There is evidence to suggest that, over this period, the site had been subjected to progressive deformation caused by the collapse of an old mine gallery. However, climatic data show that the reactivation itself was triggered by a dramatic rise in the water table induced by rapid snowmelt during a period of winter warming. Furthermore, geomorphological mapping has been used to characterise the morphology of the reactivated landslide and geophysical profiling has been used to analyse its internal structure. The results show that fissures are continuing to develop above the reactivated landslide scarp while highly saturated stiff-fissured claystones provide an incipient slide plane. The application of laser scanning has shown minimal evidence for ongoing landslide activity. It is, however, clear that future landslide events will occur here due to the favourable lithological, structural, and geotechnical conditions. Finally, we propose that future landslide activity at the site may be predicted by the height of water table as this defines theoretical pore pressure at the depth of the shear plane.
\end{abstract}

\section{Introduction}

The catastrophic landslide at Eisenberg in North Bohemia (Fig. 1a) was reactivated during January 2011, and it was the largest slope deformation to have occurred at the edge of the Most Basin since 2005 (Rybár and Novotný, 2005; Burda et al., 2011; Fig. 1a), when the side slope of a nearby open-cast mine collapsed as a result of long-term rainfall accumulation (Rybáŕ and Novotný, 2005; Burda and Vilímek, 2010). The January 2011 landslide represents the reactivation of a large complex slope deformation that has been recorded previously (Špůrek, 1974; Rybáŕ, 1997). The headscarp and eastern extension of the reactivated landslide follow the headscarp of the earlier slope deformation from 1952.

This slope deformation originally formed as a result of mining for brown coal in the Most Basin. The deep mining began at the beginning of the 20th century. It first created depressions in the overlying sedimentary layers which finally resulted in a catastrophic collapse during a landslide event that began in 1952 (Rybaŕr, 1997). This landslide led to the destruction and subsequent abandonment of the village of Eisenberg between 1952-1954. Thereafter, mining continued in the form of open-cast exploitation which further reduced the stability of the adjacent slopes (Fig. 1b).

The investigated landslide developed outside the active open-cast mining area. It occurred within a large and complex landsliding area (Burda et al., 2011) and represents one of the largest flow-like landslides in the Czech Republic (cf. Klimeš et al., 2009; Pánek et al., 2011). The toe of the accumulation flows as far as the bottom of the coal mine pit. It 


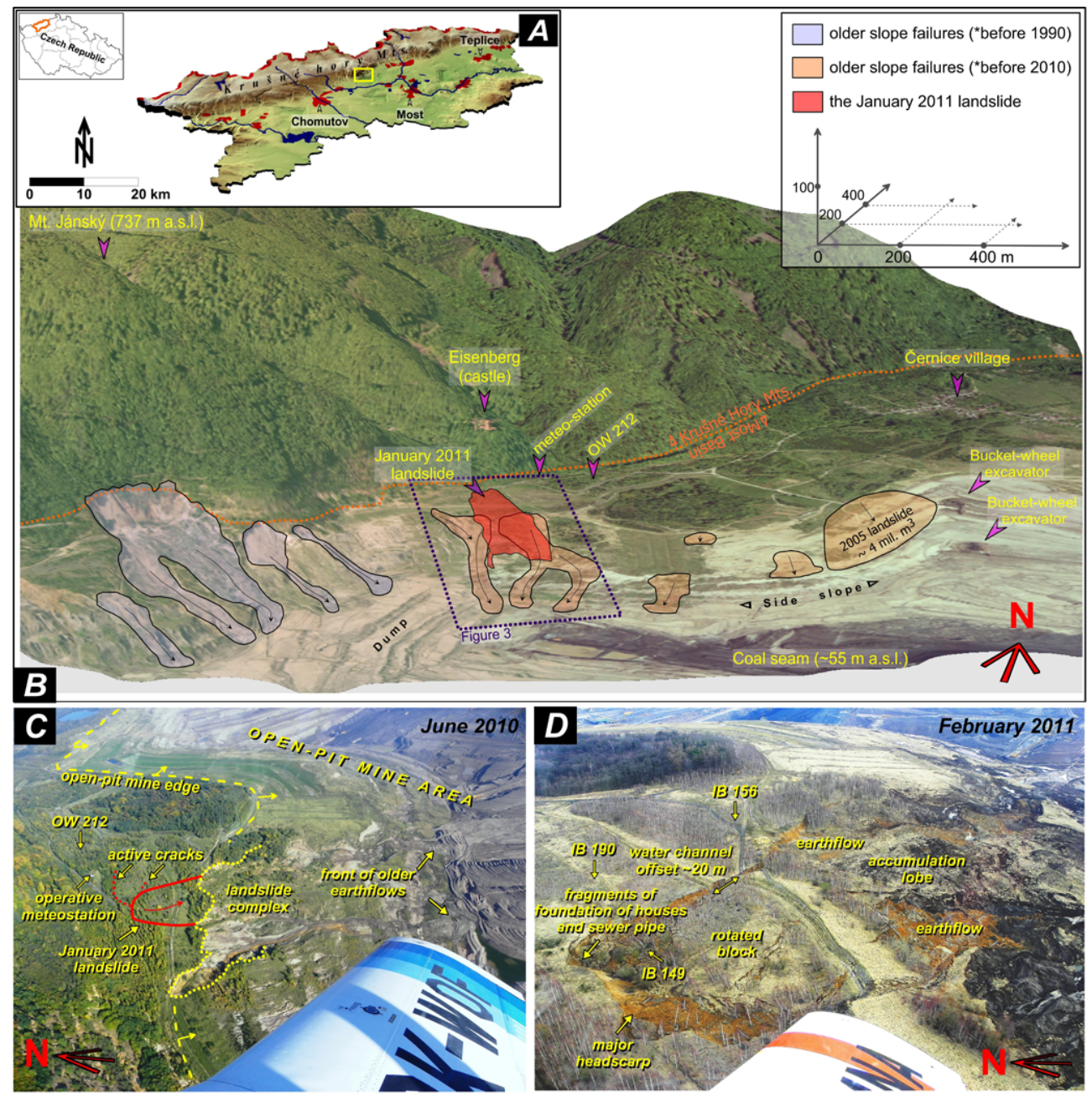

Fig. 1. (A), location of the study site; (B), three-dimensional view from SE towards structural slope of the Krušné hory Mountains. and anthropogenic relief of the Most Basin. From the 1980s until present, several slope deformations occurred within the side slope of near opencast mine (landslide situation, modified from Burda et al., 2011; DEM: Zabaged 2006); (C), an aerial overview of the landslide complex situated at the edge of the open-cast mine - the position of the landslide during January 2011 is marked by the red line, while the positions of the meteostation, observation well, and main morphological features are marked by the yellow line and arrows (foto: J. Burda, June 2009); (D), a detailed aerial view on the January 2011 landslide - the position of inclinometric boreholes is marked as well as significant morphological features (foto: J. Burda, February 2011).

was, therefore, possible to include monitoring of the minecast slopes in this study. Despite the fact that landslide reactivation had been anticipated, which reduced damage to property, the cost of the mitigation works is still expected to exceed 600000 EUR.

This paper integrates a range of geoscientific evidence in order to constrain the spatial and temporal development of this reactivation. The objectives are fivefold: first, to investigate the geodetic measurements in order to assess the development of the site over last two decades; second, to analyse the climatic data in order to constrain the trigger for the reactivation; third, to undertake geomorphological mapping in order to characterise the morphology of the reactivated landslide; fourth, to undertake geophysical profiling in order to analyse the internal structure of both the old and reactivated landslides, and fifth, to apply laser scanning in order to determine whether the slope deformation is ongoing. It should then be possible, with these data, to assess the probability of future landslide activity at the site and to suggest how this activity may be recognised.

\section{The geological and geomorphic settings}

The study area is situated along the boundary between the Krušné hory Mountains and the Most Basin (Škvor, 1975; Malkovský, 1985) at the foot of a southeasterly facing slope near the northern margin of an open-cast mine (Fig. 1). The Krušné hory Mountains comprise orthogneisses and 
various crystalline rocks, while the Most Basin comprises various Cenozoic sediments dominated by Miocene claystones, a coal seam, sands, and clastic rocks (Fig. 2). The boundary, the Krušné hory piedmont, has a graben structure (Váně, 1985) with major boundary faults and a complicated geological structure (Marek, 1983). The uplift of the Krušné hory Mountains in the Miocene-Pleistocene along the Krušnohorský Fault is expressed by the monoclonal folding of basin sediments near the edge of the mountains (Malkovský, 1977). Also as a result of uplift, the contact between these two physiographic provinces is characterised by numerous slope failures from the Miocene, Pleistocene, and late Holocene (Zmítko, 1983).

The overlying sedimentary complex comprises a group of clays and sandy clays with variable carbonate occurrence above the coal seam (Malkovský, 1985). The thickness of this overlying complex attains up to ca. $175 \mathrm{~m}$ (the maximum thickness of the entire sedimentary fill was proved at $231 \mathrm{~m}$ ). Its upper 40-60 $\mathrm{m}$ have disintegrated into shard fragments as a result of the regelation processes during the Pleistocene (Pichler, 1989). It is frequently difficult to locate the boundary between the sedimentary complex and the Quaternary sediments. This is especially the case in the vicinity of the mountain slopes. The Quaternary sediments predominately comprise coarse-grained gravels, sandy gravels, and clays with crystalline fragments. The thickness of sediments varies from $0.1 \mathrm{~m}$ to $40 \mathrm{~m}$, with the greatest thicknesses found to be associated with the alluvial fans of former tributaries flowing down from the Krušné hory Mountains. These alluvial fans contain mainly coarse-grained gravel, sands, loams, and crystalline fragments. The latter may be between $1 \mathrm{~m}$ and $5 \mathrm{~m}$ in diameter. Near the Krušné hory Mountains there are areas in which solitary boulders are found within gravel debris (Marek, 1980a). These sediments commonly form aquifers, and their saturation depends on their thickness, grain size composition, and the content of clay components. The groundwater saturation of the Quaternary sediments varies according to those factors listed. The gravels and alluvial fan sediments have good permeability (up to $10^{-4} \mathrm{~m} \mathrm{~s}^{-1}$ ) (Žižka and Halîr, 2009).

The system of the groundwater flowing is based on the configuration of Quaternary and character of basin sediments and crystalline rocks. In general the Quaternary basement descends from the north to the south or south-east, hence the groundwater flows in this direction (see Burda et al., 2011). There are two inflow types in these aquifers, which pass into each other and complement each other. The first inflow type brings water from the crystalline slopes above the Most Basin outcrops. This type shows a direct dependence on atmospheric precipitation and causes inter-annual water table fluctuations up to $1 \mathrm{~m}$. The second type of inflow is represented by permanent affluence of crystalline deep fracture system groundwater. Kaolinised granite rocks, which are linked directly to the faults, create a nearly impermeable layer, and hence cause the formation of confined aquifers

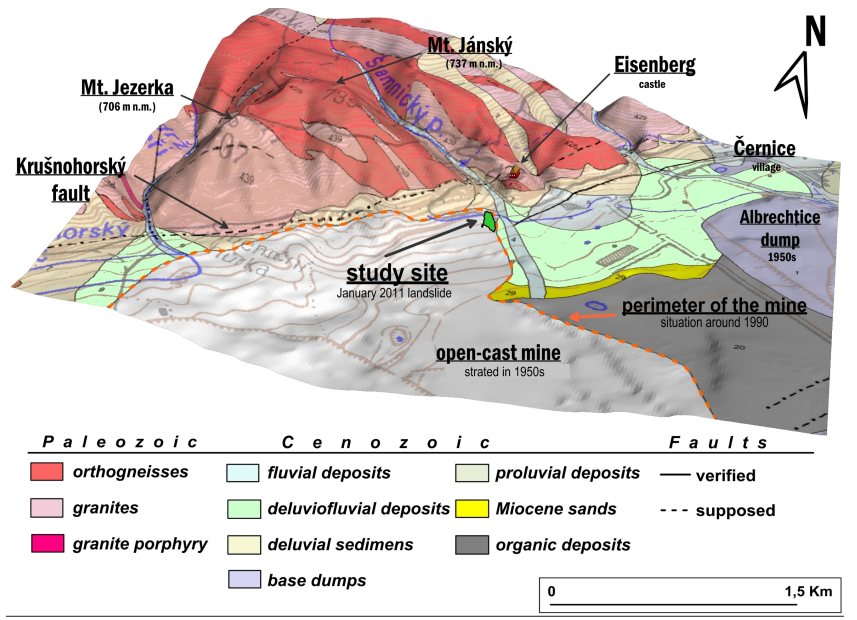

Fig. 2. General topographic and geological overview.

in the piedmont. This system is characterised by constancy without seasonal fluctuations (Žižka and Halîr, 2010).

Periodic behaviour of water table fluctuations is observed only in one observation well, OW 212 (Fig. 1b), which is placed near up to $20 \mathrm{~m}$ thick Quaternary accumulation (Burda, 2012). The seasonal water table amplitude is in the range of $0.65-0.9 \mathrm{~m}$ and reaches maximum in winter-spring and minimum in autumn-winter (Chán et al., 2011).

The geomorphological setting is influenced by structuralgeological conditions, fault tectonics, periglacial and anthropogenic processes. In addition it is also influenced by the headward erosion of the Šramnický Brook, which has incised a valley to a depth of $100 \mathrm{~m}$. The study area is situated in the mouth of this valley (Burda et al., 2011). In the 1980s a deep cut-off wall and a new channel was built in order to provide hydrogeological protection for the opencast mine. The water was captured and diverted into the new channel (Marek, 1980b). The relief is anthropogenic where the open-cast mine abuts the mountains. In this area $15 \mathrm{~m}$ high overburden benches pass seamlessly into the steep structural slope of the mountains. The inclination of this anthropogenic slope is ca. $10-15^{\circ}$ under the edge of open-cast mine (Fig. 2a), but in the mountains behind the margin of the basin the original crystalline slope is $30-40^{\circ}$. The main morphological processes that have modelled the anthropogenic slope during last two decades are those of stream erosion and mass movements.

\section{Material and methods}

\subsection{Field mapping}

The geomorphological and engineering geological mapping of recent slope deformations has been undertaken along the northwestern edge of the Most Basin since the 1960s (Váně, 1960; Špůrek, 1974; Marek, 1983; Rybáŕ, 1997). The 
fundamental morphological characteristics of the study area were assessed during geomorphological mapping of whole landslide complex in 2009 and 2010 (Burda et al., 2011). Immediately after the main movement activity in January 2011, the main deformation features were mapped at a scale of 1 : 5000 using GPS. In addition, aerial stereoscopic orthophotographs (November 2010 and March 2011) and aerial photographs (February 2011) were analysed in order to determine the overall context of the landslide, survey those accumulation areas that were inaccessible, and to estimate the total horizontal displacement. The field mapping was then compared to older maps, technical reports, and research publications (Špůrek, 1974; Rybár., 1997; and the archive of the Brown Coal Research Institute (BCRI)). This was done in order to assess the relationship between the reactivated landslide and older slope failures, to analyse the inclinometric records, and to assess anthropogenic influences.

\subsection{Geophysical profiling}

The inner structure of the landslide and its vicinity was studied using the 2-D electrical resistivity tomography (ERT). This is an elaborate method of resistivity profiling (cf. Loke, 1995; Hartvich and Valenta, 2011) that is particularly suitable for geomorphological studies as it gives insight into the subsurface (Schrott and Sass, 2006). Two-dimensional electrical resistivity tomography uses a high number of electrodes placed along a profile, and an automatic measuring unit that alternately switches the electrodes from current to potential (Loke and Barker, 1996; Dahlin, 2001). The number of electrodes, inter-electrode distances, and measurement configuration determine the depth and resolution of acquired data (Dahlin and Zhou, 2004; Loke et al., 2010). Even if the resolution decreases exponentially with depth, reasonably detailed images are usually obtained to depths of several tenths of a metre.

The main objectives of this geophysical survey were to observe the depth, course, and geometry of the sliding plane, the depth of the quaternary slope deposits, the watersaturated zones within the sliding body, and to identify any other significant phenomena. ERT was chosen as the most suitable geophysical technique, providing sufficient depth reach in contrast to other common geophysical methods such as shallow seismic refraction or GPR, while maintaining high spatial resolution and sensitivity (Schrott and Sass, 2008).

Three profiles were measured using the WennerSchlumberger array in July 2010, April 2011, and October 2011 (Fig. 3). The ARES (Automatic Resistivity System) system (by GF Instruments Brno) was used for these profiles.

The first profile $\left(A-A^{\prime}\right)$ was measured before landslide reactivation in July 2010. The aim of this profile was to assess the depth and overall character of the slope deformation (Burda et al., 2011). The profile was $186 \mathrm{~m}$ long with an electrode span of $2 \mathrm{~m}$. It crossed the most active part of the slope deformation from $\mathrm{N}-\mathrm{S}\left(175^{\circ}\right)$. The second profile

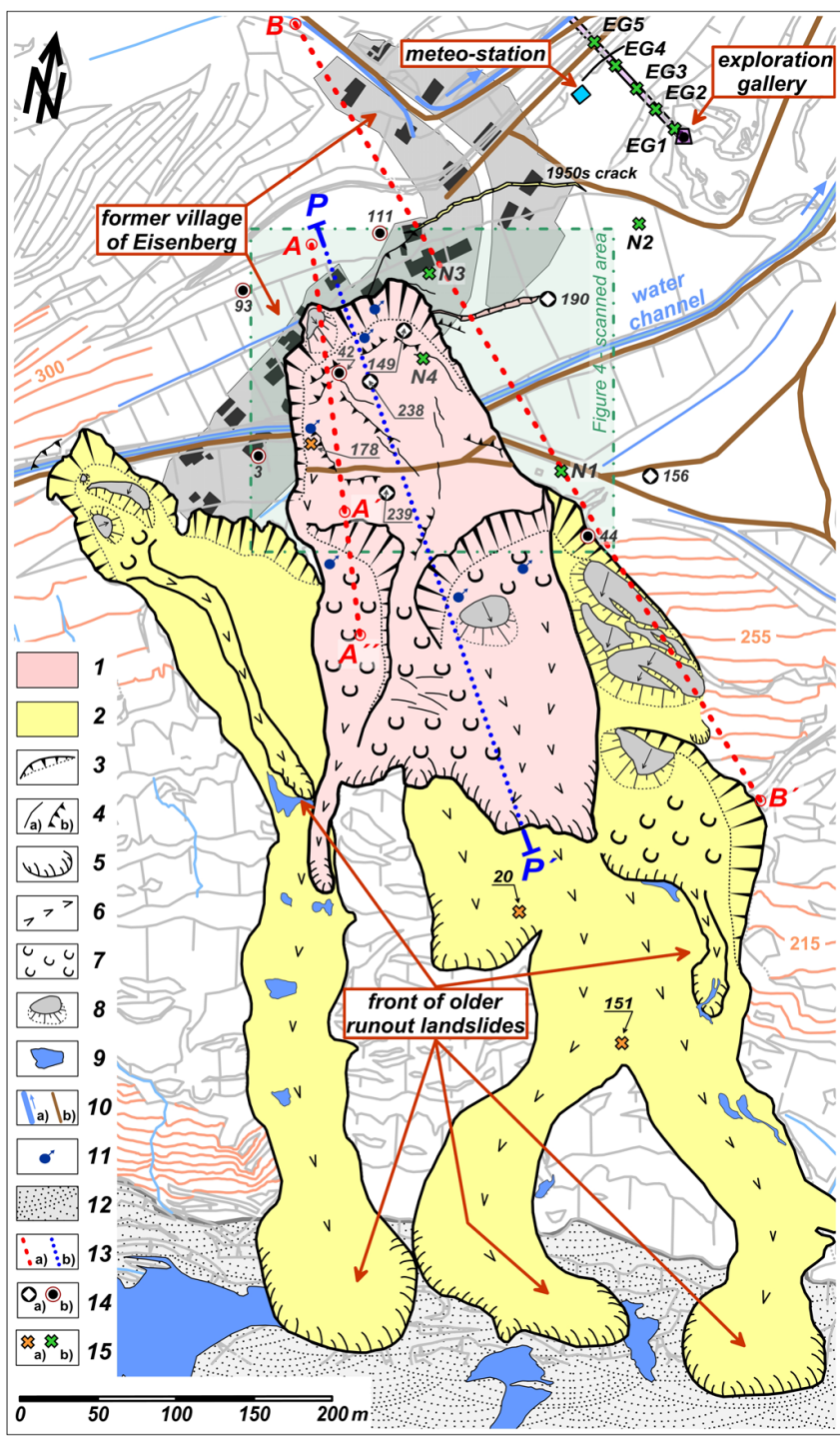

Fig. 3. A geomorphological sketch map of the area around the landslide that occurred during January 2011 - (1) the landslide of January 2011; (2) older landslides within the landslide complex; (3) headscarps; (4) (a) tension cracks, (b) tension cracks with vertical offset; (5) accumulation toes; (6) earthflows; (7) landslide accumulation surfaces; (8) landslide blocks within the landslide complex; (9) shallow colluvial depression; (10) (a) brooks and channels, (b) road; (11) spring; (12) dump; (13) (a) ERT profile, (b) longitudinal profile across the landslide; (14) (a) inclinometric borehole (b) structural test hole; (15) observed geodetic points (a) ATR - reflective prism, (b) precise niveling - bench marks.

$\left(A-A^{\prime \prime}\right)$ was measured in October 2011. This profile followed the same course as the first profile, but with an increase in the downslope length and depth penetration. The aim of this profile was to compare the results with those derived from the first profile $\left(A-A^{\prime}\right)$, i.e. before and after the landslide. The profile was $270 \mathrm{~m}$ long with an electrode span of $2 \mathrm{~m}$. The third profile $\left(B-B^{\prime}\right)$ was measured in April 2011. This 
profile is approximately parallel $\left(160^{\circ}\right)$ to the first and second profiles. It crossed a potentially active area next to the reactivated landslide. The profile was $590 \mathrm{~m}$ long with an electrode span of $5 \mathrm{~m}$.

The three profiles were taken along the slope dropline and in the direction of movement of the slide. It was thus possible to assess the depth and geometry of the sliding plane and to identify the vertical and horizontal anomalies in the resistivity. Field data (apparent resistivities) were processed using a 2-D inverse method implemented in the program Res2DInv (Loke and Barker, 1996). This resulted in a resistivity cross section that included topography.

The processed profiles were interpreted using information from nearby geological boreholes. In the 1980s and 1990s, three inclinometric boreholes were drilled in the vicinity of the profile lines (IB 149, IB 190, and IB 156; Fig. 3). The last measurements on these were taken in 2004. Borehole IB 156 was measured after the landslide in March 2011. Boreholes IB 238 and IB 239 were instrumented in September 2011. The data from the inclinometric observations were used in the interpretation of the profiles, particularly in the identification of the sliding plane depth.

\subsection{Geodetic measurements}

Precise levelling became the foundation of long-term monitoring in the area of landslide complex. The levelling measurements have been taken as a part of detailed geodetic measurements of three special levelling circuits carried out on the slopes of the Krušné hory Mountains since the 1980s (Kalvoda et al., 1990). These measurements are carried out twice every year, in spring and autumn, in accord with the methods of previous levelling measurements in the region (Kalvoda et al., 1990). To verify the movement trends and to remove measurement noise, the measurements were undertaken quarterly during the first five years. Deep-stabilised bench mark No. 124 (333.0934 m a.s.l.) of the special levelling circuit $Z_{2} b 3$ was chosen as the reference point for the surface measurements. The deeply stabilised point placed in hard rock of the exploration gallery face is the reference point for measurements within the gallery. According to Pichler and Malá (2009), standard deviation per kilometre $\left(m_{o}\right)$ is $\pm 0.0002 \mathrm{~m}$ and deviation between backsight and foresight stations measuring $(\lambda)$ does not exceed $0.0013 \mathrm{~m}$.

A geodetic network of reflective prisms was placed in the vicinity of the landslide in 2005. This could, therefore, have been used in the continuous monitoring of the nearby opencast mine (Bláha et al., 2006). This monitoring is undertaken with the Leica TCR 2003A total station and an automatic target recognition (ATR) system (Brown et al., 2007). The ATR system automatically monitors the position of all the reflective prisms at an interval of one hour. The reflective prisms are placed on $3.5 \mathrm{~m}$ long standing pipes cemented to a depth of $2 \mathrm{~m}$. The hourly measurements enable the precise calculation of daily accumulative and relative displacement (Burda and Vilímek, 2010). This eliminates the measurement error of particular aiming, which is $0.02-0.03 \mathrm{~m}$ (Hampacher et al., 2008). Three geodetic points (reflective prisms, Fig. 3) situated within the landslide and its immediate vicinity were used to describe the temporal development of movements within the slope deformation.

\subsection{Laser scanning}

Laser scanning is currently applied in many fields as a contactless method for determining spatial coordinates (Štroner and Pospísili, 2008), including monitoring of geomorphological features (Rowlands et al., 2003). During the laser scanning process, a large number of points are measured within a predefined grid covering the area of interest. It is, therefore, a particularly suitable method for generating digital terrain models (Wack and Stelzel, 2005).

The laser scanning measurements of the reactivated landslide were undertaken in March 2011, June 2011, and August 2011. These were used to generate high-resolution digital terrain models. During each campaign the landslide and its immediate vicinity were scanned with a scanning resolution of $20 \mathrm{~mm} \times 20 \mathrm{~mm}$ at a distance of $10 \mathrm{~m}$. Each point cloud, representing the measurements taken during the individual months, consists of around 4.5 million points. The measurements were all carried out in reference to a coordinate system defined by five control points located outside the limits of the reactivated landslide. The subsequent comparison and analysis of the digital terrain models assessed the surface movements that occurred between the three months in which the laser scanning was undertaken. The measurements were made using the Leica HDS3000 laser scanning system with a position accuracy of $5 \mathrm{~mm} / 100 \mathrm{~m}$ and an angular accuracy of $0.06 \mathrm{mrad}$.

\subsection{Climatological analyses}

The influence of climatic factors on slope stability is generally accepted (Schuster and Wieczorek, 2002), and has been confirmed in the study area by specific case studies (Rybár and Novotný, 2005; Burda and Vilímek, 2010). The data from a meteostation, operated by the BCRI, situated near the landslide have been analysed to investigate the possible causes of reactivation (Fig. 3). These data comprise hourly measurements of air temperature and precipitation. The snow layer thickness was calculated from data recorded at four climatological stations, at between $6 \mathrm{~km}$ and $60 \mathrm{~km}$ from the reactivated landslide, by the Czech Hydrometeorological Institute (Table 1). The reference Quaternary observation well OW 212 is located $450 \mathrm{~m}$ north-east of the reactivated landslide (Fig. 1). 
Table 1. A comparison of the maximum recorded snow cover thicknesses at selected climatological stations with those recorded during the winter of 2010-2011 (Data source: Czech Hydrometeorological Institute).

\begin{tabular}{|c|c|c|c|c|}
\hline \multirow{2}{*}{ Meteostation } & \multirow{2}{*}{$\begin{array}{r}\text { Elevation } \\
\text { (m a.s.1.) }\end{array}$} & \multirow{2}{*}{$\begin{array}{l}\text { Distance from } \\
\text { the landslide }\end{array}$} & \multicolumn{2}{|c|}{$\begin{array}{c}\text { Snow cover } \\
\text { thickness }(\mathrm{mm})\end{array}$} \\
\hline & & & $\begin{array}{r}\text { 2010/2011 } \\
\text { max. }\end{array}$ & $\begin{array}{l}\text { hist. } \\
\text { max. }\end{array}$ \\
\hline Nová Ves v Horách* & 725 & $6 \mathrm{~km}$ & 810 & 810 \\
\hline Ústí nad Labem & 375 & $40 \mathrm{~km}$ & 310 & 310 \\
\hline Milešovka & 836 & $30 \mathrm{~km}$ & 540 & 550 \\
\hline Karlovy Vary & 606 & $57 \mathrm{~km}$ & 450 & 450 \\
\hline
\end{tabular}

* Identical orographic conditions as the Eisenberg watershed.

\section{Results}

\subsection{The morphology and internal characteristics of the landslide}

\subsubsection{Description of the landslide morphology}

The studied landslide constitutes the reactivated component of a large complex slope deformation initiated in 1952 (Špůrek, 1974; Rybář, 1987). The geomorphological mapping reveals a $1.5 \mathrm{~m}$ high headscarp and a series of tension cracks together with sagging of the landslide mass in the scarp area of the developing landslide. This disturbed area reflects the surface outcrop of a developing shear plane that has been described previously by Rybáŕr (1997). It is thought that the origin of this shear plane dates back to the 1990s. The reactivated landslide can be described as a complex landslide (Dikau, 2004) as it was characterised by a change in motion mechanics from sliding to flowing (Figs. 1 and 3). The body of the reactivated landslide consists of a rotated block with a length of ca. $150 \mathrm{~m}$ and a width of ca. $120 \mathrm{~m}$ together with a long frontal accumulation lobe that has flowed over the scarps of older earthflows.

The headscarp is located at an elevation of ca. $295 \mathrm{~m}$ a.s.l. It has a typical amphitheatral shape with a width of $102 \mathrm{~m}$ and a height of up to $13 \mathrm{~m}$. In the outcrop of the headscarp it is possible to see the soil, bouldery gneiss proluvium, weathered claystones, and interbedded overlying sands. Fragments, mainly ruined building foundations, from the former village of Eisenberg were found in the eastern part of the headscarp (Fig. 1). The remains of a sewer pipe were also found, from which water was still being discharged one week after the landslide at roughly $1-5 \mathrm{~L} \mathrm{~s}^{-1}$. The main scarp continues to the northeast in the form of a significant tension crack that runs for $200 \mathrm{~m}$. This probably defines the unstable part of the reactivated landslide. On the western side a smooth shear plane is exposed with an inclination of up to $30^{\circ}$. On the eastern side a minor scarp with a height of 5-7 m defines the limit of the reactivated landslide body.
The landslide body has shifted horizontally, as determined from orthophotographic analysis. The upper part of rotated block, below the headscarp, has shifted by $12-14 \mathrm{~m}$, while the middle part, including the road and artificial water channel, has shifted by 23-25 m (Fig. 4b). The area of older headscarps in the lower part has shifted up to $26.4 \mathrm{~m}$. At elevations of 250-265 $\mathrm{m}$ a.s.l., the frontal part of the landslide body was thrust over the upper overburden bench which meant that the material lost its cohesion and was subsequently deposited upon the eroded overburden benches and older earthflows (Fig. 3). This accumulation lobe has a length of ca. $150 \mathrm{~m}$ and the characteristics of an earthflow on both the western and eastern sides where the material was fully saturated and without cohesion.

\subsubsection{The internal structure of the landslide}

The resistivities along profile $A-A^{\prime}$ span from 5 to $800 \Omega \mathrm{m}$ (Fig. 5). The soil horizon is seen at depths ranging from 0.5 to $2.5 \mathrm{~m}$. Below this lie the non-conductive coarse gravel slope deposits (in the borehole record these are described as bouldery gneiss proluvium). The base of these deposits is seen at depths ranging from $8 \mathrm{~m}$ to $13 \mathrm{~m}$. The substratum comprises the markedly conductive stiff-fissured Miocene clays (an assumed water-bearing shear plane; Fig. 6), but with more sandy facies between stations 46 and 56 . The Tertiary sedimentary fill of the Most Basin has the character of a quasi-homogeneous discontinuous environment where the anisotropy is applied (Rybáŕ, 1978). The Miocene clays are characterised by a dense system of fault planes and joints as well as the original bedding planes. In addition to the highly variable primary and secondary fissure permeability, infiltration is also influenced by the fracturing caused by regelation prior to the Holocene. The headscarp area is characterised by a sub-vertical conductive zone disrupting the high resistivity layer between stations 64 and 75 . The depth of the shear plane from this profile was estimated to be $15 \mathrm{~m}$ (Burda et al., 2011). Boreholes IB 149 and IB 190 were sheared by the movement of the landslide at depths of 12-14 m (Fig. 7).

The main structures found on profile $A-A^{\prime}$ are all visible on profile $A-A^{\prime \prime}$ (cf. Fig. 5: middle and bottom). Profile $A-A^{\prime \prime}$ clearly shows that the landslide body predominately comprises coarse, gravelly slope deposits. The shear plane, however, passes through the stiff-fissured claystones at depths of $15-20 \mathrm{~m}$. This is a zone of sensitive clays, according to Pletichová (2006). The zone of very low resistivity between stations 230 and 280 reflects a water-saturated accumulation lobe formed by a mixture of Quaternary and weathered Miocene sediments. These sediments have been deposited on the eroded overburden benches of the open-cast mine (Fig. 6). This accumulation has the characteristics of an earthflow and cannot be distinguished on the profile from the underlying conductive claystones.

Profile $B-B^{\prime}$ (Fig. 5) starts in clearly identifiable crystalline bedrock (paragneisses according to the geological 

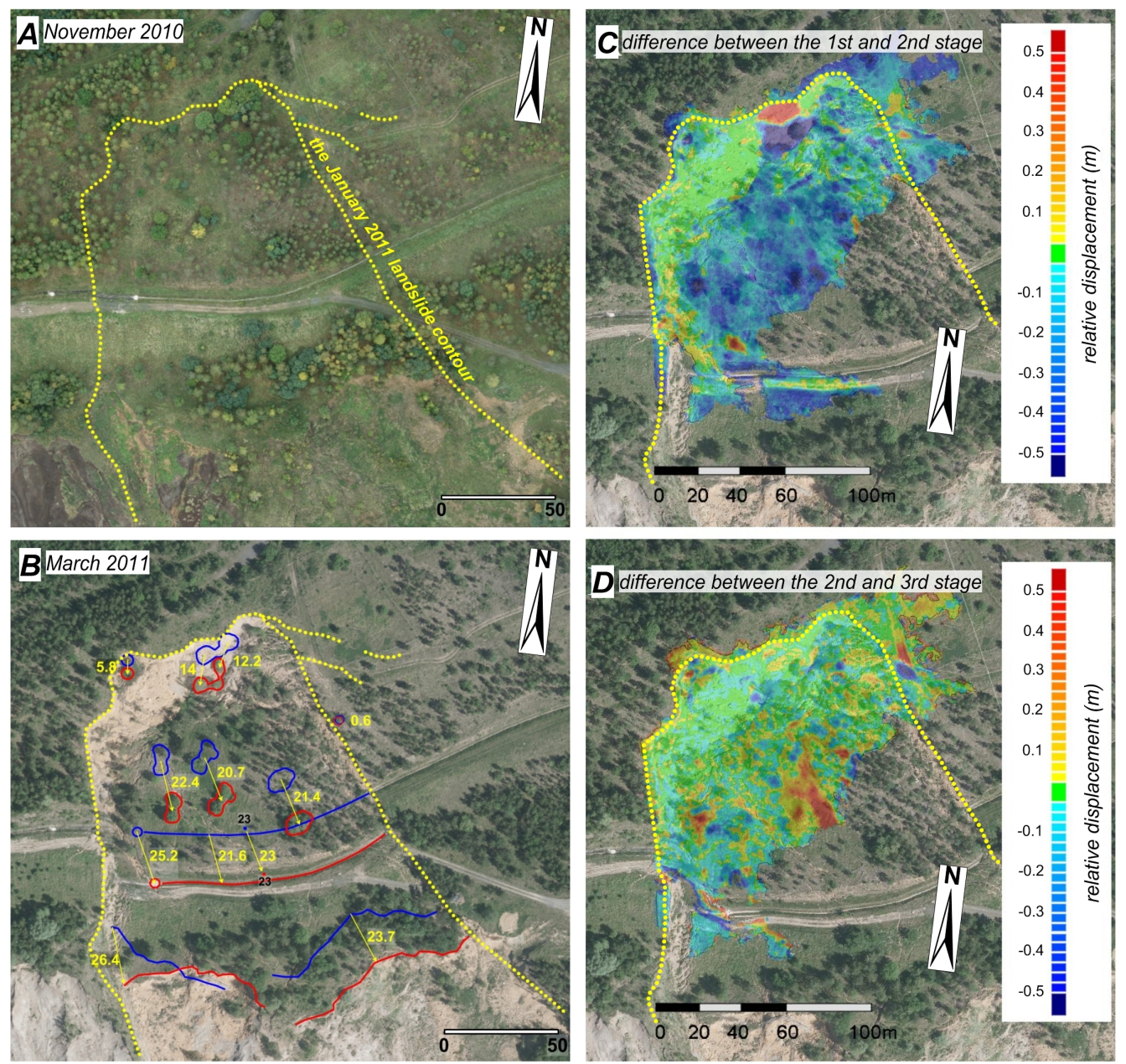

Fig. 4. Left: the orthophotos from 2010 and 2011 with the contours of the landslide body (dashed yellow line). (A), the situation before the landslide. In (B) the orthophoto from 2011 shows the original (blue) and displaced (red) positions of selected objects for which the displacement vectors (yellow arrows) and horizontal displacement in metres (yellow numbers) were identified. Point 23 represents a key geodetic marker as its position was measured both before and after the main period of landslide activity. Right: the differential models that show the relative displacement within the body of the landslide in 2011. (C) presents the difference between the 1st and 2nd stage, while (D) presents the difference between the 2nd and 3rd stage.

map and borehole documentation). The bedrock loses some of its compactness towards station 100 , as reflected by decreasing resistivity. The zone of very low resistivity between stations $100-150$ is interpreted as the Krušnohorský Fault. It is one of the most prominent and active faults along which the tectonic basin has descended. The fault is steeply inclined towards the basin at $75-80^{\circ}$. Its presence is corroborated by two of the borehole records which penetrated the rock massif to depths of $90 \mathrm{~m}$ and $117 \mathrm{~m}$ (STH 111 and STH 6; not shown on Fig. 5). A high resistivity surface layer is seen along the top of the profile at depths of between $10-15 \mathrm{~m}$, although in places it reaches depths of $20-25 \mathrm{~m}$ (e.g. between stations 325-375) and it is virtually absent between stations 115-150. The thickness of $15 \mathrm{~m}$ at station 390 corresponds well to that found in the nearby borehole STH 44. This is again the coarse gravel slope deposits, which also form the body of the nearby landslide. Underlying the high resistivity surface layer is a zone of very low resistivity and highly variable thickness $(15-50 \mathrm{~m})$. This zone most likely reflects wet clays, which are also observed below $15 \mathrm{~m}$ in boreholes IB 190 and STH 44. It is probable that any future extension of the landslide would be activated along this slide plane. Here, two incipient scarps were observed (at station 185 and 275 - see also on Fig. 3), as well as a verified shallow aquifer. The varying resistivities probably reflect the varying physical properties of the clay. The higher resistivities may be associated with dryer and more compact claystones, possibly with a greater sand content. In some places these dry claystones separate water saturated clays (e.g. station 330). 

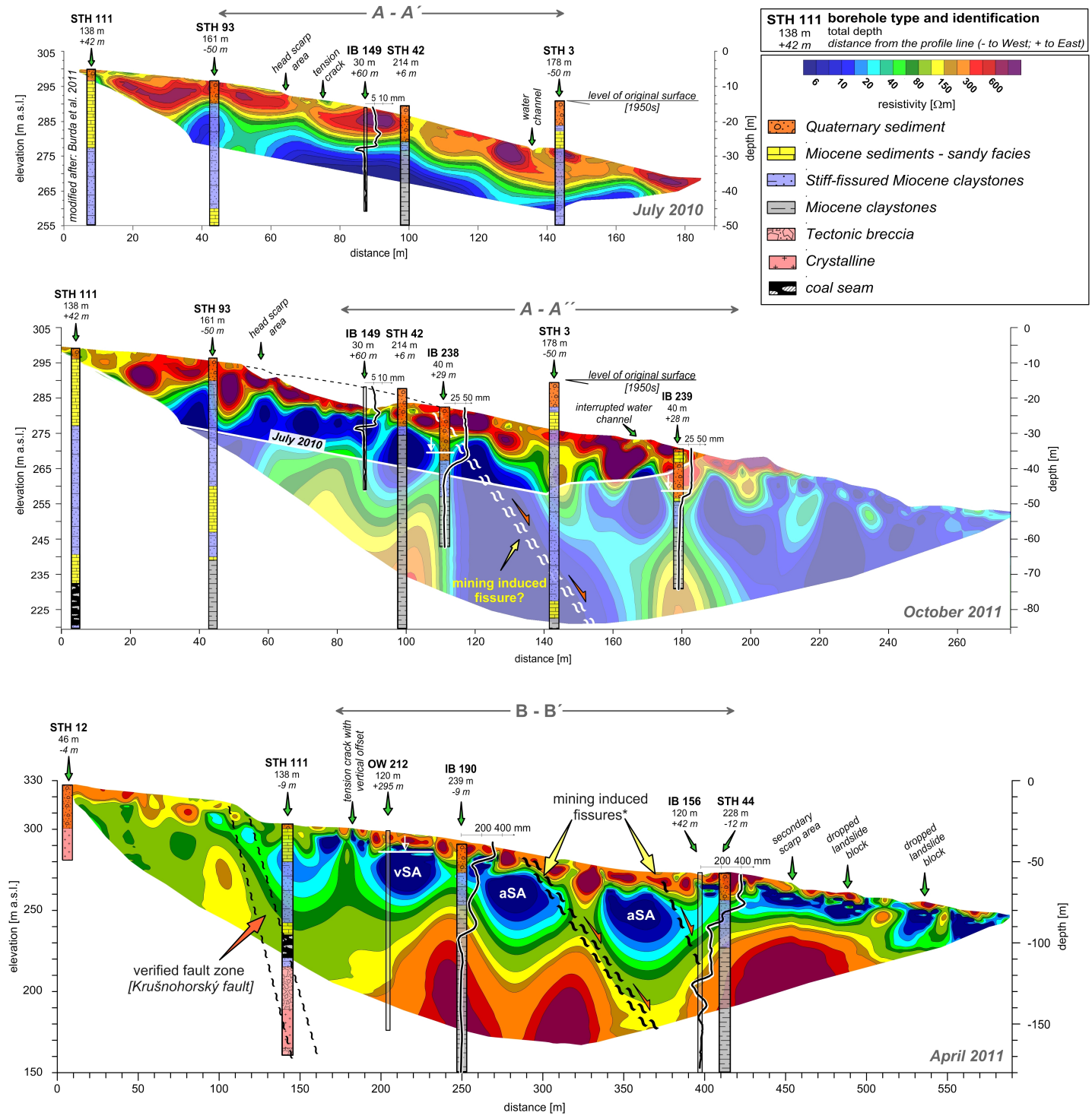

Fig. 5. The ERT profiles taken across the landslide (locations depicted on Fig. 2). STH: structural test hole; IB: inclinometric borehole; OW: observation well; vSA: verified shallow aquifer; aSA: assumed shallow aquifer.

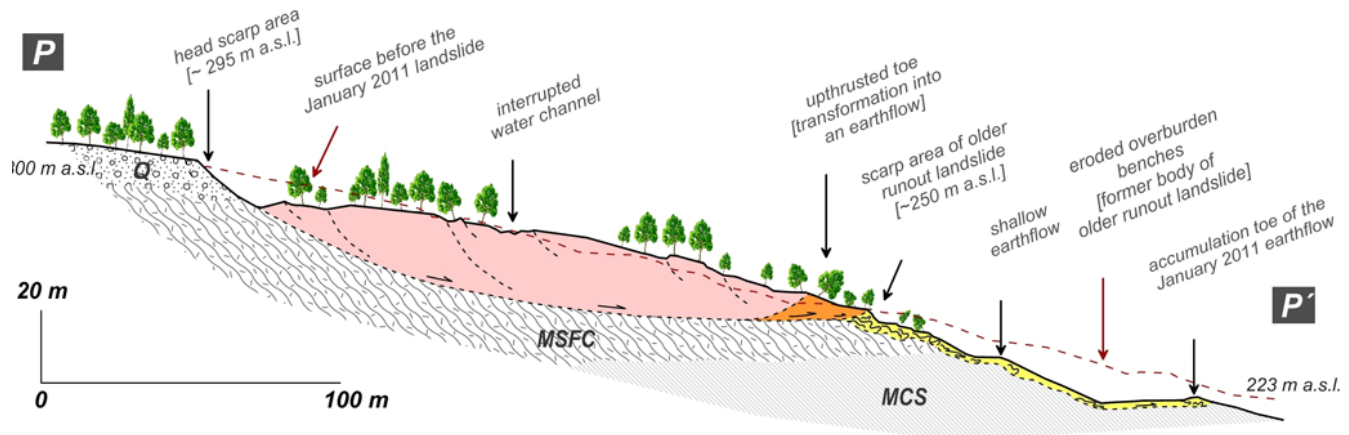

Fig. 6. A generalised longitudinal profile taken across the landslide during January 2011. The profile is based on geomorphological field mapping, ERT interpretation, and the analysis of IB 149, IB 238, and IB 239. Its location is shown in Fig. 2 (Q: Quaternary sediments; MSFC: Miocene stiff-fissured claystones; MCS: Miocene claystones (solid)). 


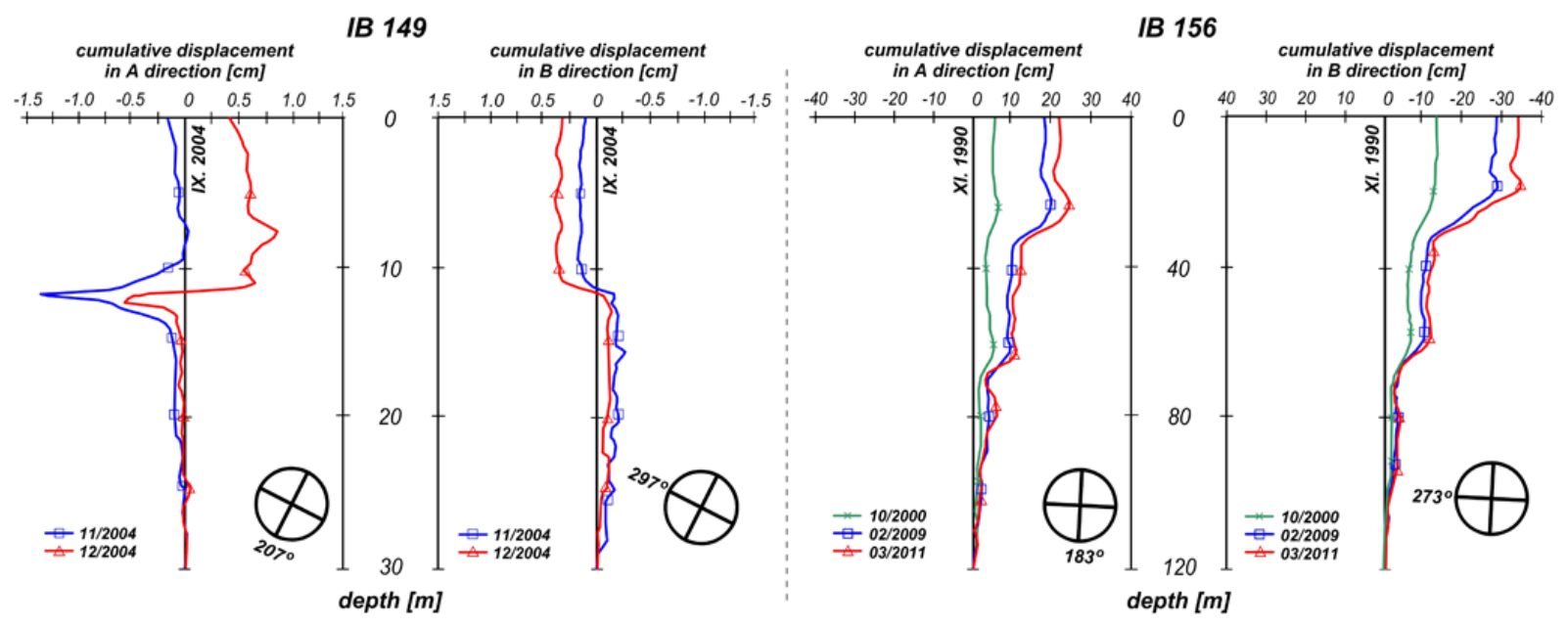

Fig. 7. Selected inclinometric boreholes - cumulative displacement. IB 149 was placed within the landslide body; the initial shear failure is obvious at the depth of $12 \mathrm{~m}$ - last measurement was in December 2004. Two zones of possible shear failure are visible in IB 156 placed near the January 2012 landslide. The main landslide activity was reflected also in this borehole when the shift of $60 \mathrm{~mm}$ was found in the upper shear zone.

\subsection{The development of the landslide since the $1990 \mathrm{~s}$}

The development of the landslide since 1990 can be investigated using the results of the precise levelling of benchmarks N1-N4. The measured accumulative displacement values are shown on Fig. 8. It is clear that significant movements have been recorded at all four measuring sites. The mean rate of movements at N1 and N2 was linear from 1993-2010 (6.4 $\mathrm{mm} \mathrm{yr}^{-1}$ and $9.4 \mathrm{~mm} \mathrm{yr}^{-1}$, respectively). However, at $\mathrm{N} 3$ and N4 the mean rate of movements accelerated significantly after 2008 (from $19.5 \mathrm{~mm} \mathrm{yr}^{-1}$ to $31.5 \mathrm{~mm} \mathrm{yr}^{-1}$ and from $21 \mathrm{~mm} \mathrm{yr}^{-1}$ to $55.5 \mathrm{~mm} \mathrm{yr}^{-1}$, respectively). The longterm development of the landslide was also reflected by all five points located within the exploration gallery. The vertical shift was between 1.2-4.2 $\mathrm{mm} \mathrm{yr}^{-1}$ during the $1990 \mathrm{~s}$ and has been between $1.6-2.4 \mathrm{~mm} \mathrm{yr}^{-1}$ for the past $11 \mathrm{yr}$. These movements were accompanied by crack extension at between $61.5-85.6 \mathrm{~m}$ from the entrance to the gallery. The extension is characterised by acceleration in the spring and deceleration in the winter, as previously described by Kalvoda et al. (1990) and Rybáŕ (1997).

The reactivated landslide activity was well documented by $\mathrm{N} 1(-20.5 \mathrm{~mm})$ and N3 (-37.3 mm) (Fig. 8). N4, situated in the scarp area, was destroyed with the vertical drop calculated from the stereoscopic orthophotographs, thought to be ca. $5 \mathrm{~m}$. Furthermore, detailed information about development of the landslide in 2010 was recorded by the automatic target recognition monitoring of reflective prism No. 178 . This was placed in the landslide in June 2009. This point showed linear deformation during the first year of monitoring as well as the first period of acceleration in spring 2010 and subsequent deceleration during summer 2010. The main movement occurred in January 2011, but the movement velocity started to increase during December 2010 (Fig. 8).
Between 9 and 14 January 2011, the daily rate of movement increased steadily to $20 \mathrm{~mm} \mathrm{day}^{-1}$. On 15 January at 8:01 p.m., reflective prism No. 178 was measured for the last time, with a total accumulative displacement of $777 \mathrm{~mm}$. The ATR system, assuming that it had not been completely destroyed, would be able to find the reflective prism if it was within $5.5 \mathrm{~m}$ of its previous position (Bláha et al., 2006). It is thought, therefore, that the final movements were sudden and relatively fast $\left(\mathrm{m} \mathrm{h}^{-1}\right)$, with the point destroyed shortly after reactivation of the landslide.

\subsection{The development of the reactivated landslide since 2011}

The laser scanning data were processed in stages, and the primary output from each was a three-dimensional terrain model (Fig. 4c and d). It is clear that a problem occurs during the generation of these models that stems from the presence of vegetation within the area of interest. The problem may result from trees within the landslide and the long grasses that grew during the summer months, and although special software was used to filter these points, the quality of the measured data was significantly affected. The generated digital terrain models were then used to create hypsometric models that characterised the differences in terrain form that have developed between the individual stages. These may not be wholly accurate where the measured data have been compromised by the occurrence of vegetation, i.e. in the lower part of the landslide where movements of $100 \mathrm{~mm}$ have been recorded between individual stages. In contrast in those places where no vegetation has regenerated, such as in the headscarp, the differential models accurately reflect the changes that have occurred between individual stages. 


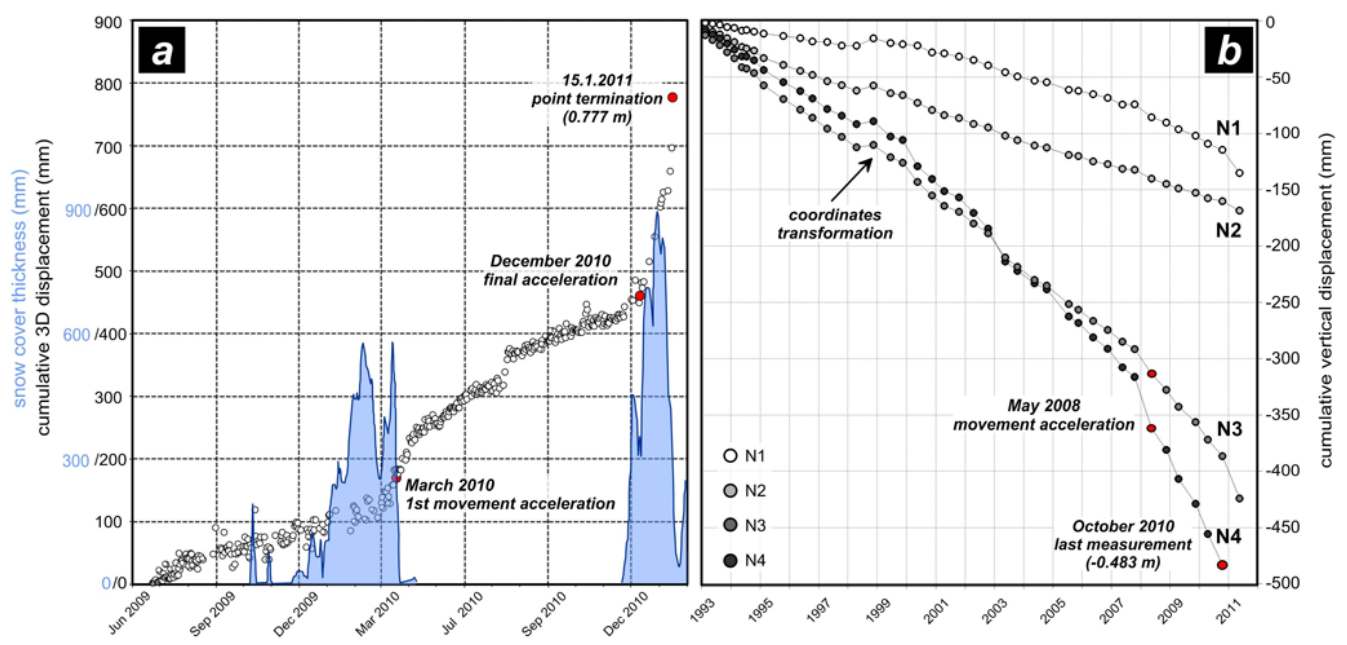

Fig. 8. (A), a cumulative three-dimensional displacement and snow melting (at NV station) versus time diagram showing the development of the landslide in the two years prior to January 2011. It is clear that there are two cycles of acceleration: the first in March 2010 and the second in December 2010. (B), a cumulative vertical displacement versus time diagram measured on four niveling bench marks since the 1990s.

The first differential model, between the 1st and 2nd stages, shows the separation of a large block from the headscarp (block diameter: ca. $5 \mathrm{~m}$ ). The total movement at this location was $960 \mathrm{~mm}$. The toe of the landslide, as a result of soil slip, moved by up to $450 \mathrm{~mm}$. However, it is also clear from the first differential model that on the rest of the area is associated with no or very small shifts of less than $100 \mathrm{~mm}$ (Fig. 4c and d (blue)). The second differential model, between the 2nd and 3rd stages, shows a number of localised movements of the soil at the edge of the landslide (Fig. 4c and d (light yellow and light blue)). These movements attain maximum distances of $180 \mathrm{~mm}$. It appears that the base of the landslide has moved by up to $500 \mathrm{~mm}$. However, this area was covered with tall grass, the occurrence of which greatly influenced the measured data and its quality. It is, therefore, not possible to say with certainty whether these movements are real or apparent.

\subsection{The trigger for landslide reactivation}

The winter of 2010-2011 was characterised by a greater than average snow cover in North Bohemia. At three of the four selected meteorological stations, the measured snow cover was the highest ever recorded, while it was only slightly less than the highest ever recorded at the fourth station (Table 1). In addition the progressive development of the winter snow cover was unusual when set against previous years. In 20102011 the peak snow cover at all stations was recorded in the second half of December, whereas in recent years it has normally occurred in the second half of January or in February (Fig. 9a-d). The rapid cooling in late November and early December was followed by considerable warming that began on 7 January. From 7 to 16 January, the temperature did not drop below $0^{\circ} \mathrm{C}$. The average daily temperature reached $7^{\circ} \mathrm{C}$ on the 14 th and $6^{\circ} \mathrm{C}$ on the 15 th. The maximum temperature recorded during this period was $10.7^{\circ} \mathrm{C}$ on the 16 th. In central Europe this type of December-January warming may occur on isolated days (Rybáŕ, 2001). The protracted nature of this warming event makes it unique, at least for the meteostation Jezeř́. It lead to rapid melting of the record snow cover with an estimated snow water equivalent of ca. $200 \mathrm{~mm}$ (Čekal et al., 2011) and an immediate rise in the water table (Fig. 9e). The total precipitation measured at Jezeří was $7 \mathrm{~mm}$ (13-15 January). The records of other meteorological stations demonstrate that this rapid thaw occurred throughout the Krušné hory Mountains, which was immediately followed by the landslide mobilisation (Fig. 8).

However, the final movement acceleration occurred at the beginning of December 2010 when a separate warming event on 11 December led to partial melting of snow and subsequent rising of water table. On 11 December the average temperature was $2.8^{\circ} \mathrm{C}$ and the daily maximum was $4.9^{\circ} \mathrm{C}$, while there was also $7 \mathrm{~mm}$ of rainfall (Fig. 9). The subsequent saturation of the material led to the mobilisation of the older earthflow masses. This mobilisation destroyed geodetic points 20 and 151 (Fig. 3) on 13 December (i.e. with a two-day lag following the temperature peak).

\section{Discussion}

The original 1950s slope deformation occurred as a result of surface subsidence due to the collapse of parts of the gallery at Koněv Mine (Špůrek, 1974). It deformed the entire mass of overlying rocks and, at least in part, contributed to the development of deep-seated fault planes. These subsidenceinduced fault planes enable water from the permanent and 

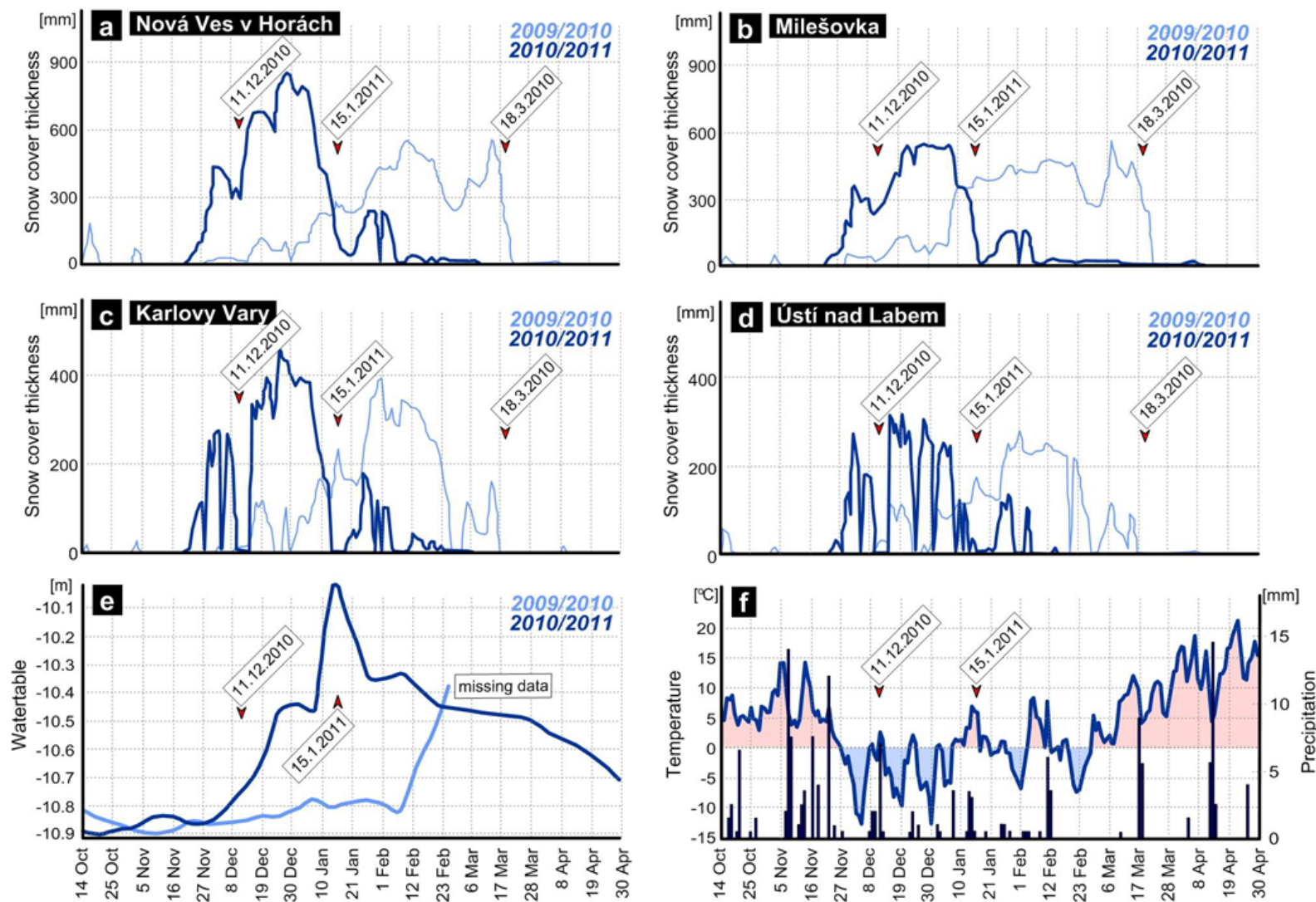

Fig. 9. The main triggering factors of the landslide reactivation (15 January 2011) were rapid melting of snow cover in the beginning of December 2010 and January 2011 (a-d) and a sudden increase in the water table in OW 212 (e). These factors resulted from the increase in average temperature (Jezeří meteostation) during January (f) (Data sources: Czech Hydrometeorological Institute; the meteostation Jezeří operated by BCRI; Chán et al., 2011).

intermittent aquifers to infiltrate more easily into the underlying claystones and to thereby become a significant mechanical discontinuity surface.

The system of fractures and fissures further accelerates the flow of water through the colluvial mantle as well as accelerating groundwater flow in the claystones $\left(10^{-6} \mathrm{~m} \mathrm{~s}^{-1}\right)$. The results of Pletichová (2006) and the electrical resistivity tomography support this hypothesis by showing three very low resistivity zones (less than $5 \Omega \mathrm{m}$ ) - these represent aquifers in the stiff-fissured claystones. The high-resistivity body of the landslide, formed by permeable slope deposits, overlies this water-saturated zone. The bases of the profiles are also associated with high resistivity zones that most likely reflect impermeable $\left(<10^{-8} \mathrm{~m} \mathrm{~s}^{-1}\right)$ dry compact claystones. These sensitive stiff-fissured claystones hold water in the aquifer and thereby create an ideal sliding plane for the landslide (also confirmed by the inclinometric boreholes). They are characterised by a liquid limit of ca. $73 \%$ and a plasticity index of ca. $23 \%$ (Pichler, 1989), while exhibiting a large difference between the fully softened and residual friction angles (mainly in the upper $30-40 \mathrm{~m}$ with low diagenetic hardening). It is thought that the mobilised shear strength is lower than the fully softened shear strength and is approaching the residual value in these stiff-fissured claystones (Stark and Eid, 1997). Hence, the value of safety factor (SF) well reflects the interannual fluctuations of water table respective of pore water pressure, and the landslide activity followed changes in dry/wet periods of the year.

The landslide reactivation was the culmination of a progressive development which has been caused by the ongoing weakening of resisting forces. Since 1990 the movement has been characterised by linear creep. Then, in 2008, it was decided that water captured by the cut-off wall should no longer be pumped away. The intercepted waters reached the top of the cut-off wall and, subsequently, soaked into surrounding sediments and penetrated into the landslide area (Burda et al., 2011). This lead to the sudden movement acceleration outlined above. The water flowed through the permeable mantle and into stiff-fissured claystones, while the solid crystalline basement rocks prevented deeper water penetration. Function of the cut-off wall was restored by the mining company at the end of 2011 on the basis of research and recommendations (Pichler et al., 2011; Burda et al., 2011). Therefore an improvement in the stability is expected for the time being, 
but further geotechnical and hydrogeological monitoring is necessary because the average slope gradient still exceeds $9^{\circ}$.

This study and that of Burda et al. (2011) show that finding these zones through the application of electrical resistivity tomography is essential to estimation of minimum depth and geometry of the shear plane. This method, combined with detailed field mapping, improves our ability to predict the depth and extent of future landslide activity. It is seen that profiles $A-A^{\prime}, A-A^{\prime \prime}$, and $B-B^{\prime}$ all have analogous zones of low resistivities (ca. $5 \Omega \mathrm{m}$ ). Profile $B-B^{\prime}$ was taken outside the area affected by the reactivated landslide. However, the geotechnical conditions along that profile suggest that future landslide activity should also be expected here. In addition the influence of the January landslide was also observed in the inclinometer borehole IB 156, which is placed out of the main landslide but near the profile $B-B^{\prime}$ (Fig. 7). The main landslide activity was reflected by the shift of $26 \mathrm{~mm}$ to the south (azimuth $183^{\circ}$ ) and of $48 \mathrm{~mm}$ to the west (azimuth $273^{\circ}$ ) in the depth of $23-35 \mathrm{~m}$. It is also known that the claystones forming anthropogenic slopes are unstable over protracted periods if the mean slope gradient is greater than $9^{\circ}$.

Further research must focus on developing a systematic monitoring system. In this region the majority of landslide early warning systems are based only on geodetic methods (Bláha et al., 2006). However, a seven year observation of the water table at OW 212 (Burda and Vilímek, 2010; Chán et al., 2011) has shown that this may also provide a suitable basis. The movement accelerations always occurred when the water table rose above $-10.25 \mathrm{~m}$, which corresponds to a theoretical pore pressure of $68 \mathrm{kPa}$ at the depth of the shear plane. This can be understood as a threshold value above which landsliding may be initiated (as happened in 2005, 2006, 2007, 2008, 2009, 2010, and 2011). It seems this pore water pressure $(\sim 68 \mathrm{kPa})$ lead to a reduction of the mobilised shear strength which is approaching the residual value and is the prime cause of landslide reactivations. This hypothesis does, however, need further investigation in order to better understand the influence of other factors such as rainfall and snow water equivalent.

\section{Conclusions}

This study has integrated a range of geoscientific evidence in order to constrain the spatial and temporal development of the reactivated catastrophic landslide at Eisenberg in North Bohemia. The key findings presented in this paper are the following:

- The geodetic measurements have shown that, over the past two decades, the site had been subjected to progressive deformation caused by the collapse of an old mine gallery.
- The climatic data have shown that the reactivation itself was triggered by a dramatic rise in the water table (and subsequent pore water pressure increase up to $68 \mathrm{kPa}$ ) induced by rapid snowmelt during a period of winter warming.

- The geomorphological mapping and geophysical profiling have shown that fissures are continuing to develop above the reactivated landslide scarp, while highly saturated stiff-fissured claystones provide an incipient slide plane.

- The laser scanning shows that there is little evidence for ongoing landslide activity.

The landslide will continue to develop in the future due to the favourable lithological, structural, and geotechnical conditions. It is thought the endangered area may extend as far as the Krušnohorský Fault. It is proposed that future landslide activity at the site may be predicted by the height of water table as this defines a theoretical pore pressure causing a critical decrease in effective stress and therefore a reduction of the mobilised shear strength. In September 2012 four new observation wells were placed near the headscarp of the landslide complex in order to improve water table monitoring and accurate description of the displacement mechanisms in relation to the pore water pressures.

Acknowledgements. The research was funded by the grant project "GA UK 155610", project CzechGeo/EPOS (proj. No. LM2010008) and by the grant project "SVV 265-212".

The authors would also like to acknowledge the help of their colleagues Jan Klimeš, Jiří Dohnal and Tomáš Nýdl for their assistance during field research and geophysical profiling.

The authors would also like to thank Matthew Rowberry for language editing and for his advice that helped to improve the paper.

Edited by: A. Günther

Reviewed by: two anonymous referees

\section{References}

Bláha, J., Blín, J., and Stanislav, P.: Nový system sledování bočních svahů lomu ČSA, Zpravodaj Hnědé uhlí, 1, 20-27, 2006 (in Czech).

Brown, N., Kaloustian, S., and Roeckle, M.: Monitoring of open pit mines using combined GNSS satellite receivers and robotic total stations, available at: www.leica-geosystems.com/downloads123/zz/monitoring/ geomos/tech_paper/Brown_Monitoring_with_combined_GNSS_ and_robotic_total_stations.pdf (last access: 10 October 2011), 2007.

Burda, J. and Vilímek, V.: The influence of climate effects and fluctuations in groundwater level on the stability of anthropogenic foothill slopes in the Krušné Hory Mountains, Czechia, Geografie, 115, 377-392, 2010. 
Burda, J., Žižka, L., and Dohnal, J.: Monitoring of recent mass movement activity in anthropogenic slopes of the Krušné Hory Mountains (Czech Republic), Nat. Hazards Earth Syst. Sci., 11, 1463-1473, doi:10.5194/nhess-11-1463-2011, 2011.

Burda, J.: Dynamics and spatial extension of recent landslides at the foot of Krušné Hory Mts., Ph.D. thesis, Charles University, Prague, 2012.

Čekal, R., Ryglewicz, M., Fryč, T., Boříková, L., Suchá, M., Přibyl, J., and Kotek, R.: Zpráva o povodni v lednu 2011, CHMI, Prague, 2011 (in Czech).

Chán, B., Mrlina, J., Seidl, M., Polák, V., and Skalský, P.: Monitoring of inclinations and water table in the area Jezeří, Institute of Geophysics, Prague, 2011 (in Czech).

Czech Hydrometeorological Institute: available at: http://www. pocasi-volary.cz/velhartice/snow.php, last access: 30 June 2011.

Dahlin, T.: The development of DC resistivity imaging techniques, Comput. Geosci., 27, 1019-1029, 2001.

Dahlin, T. and Zhou, B.: A numerical comparison of 2D resistivity imaging with 10 electrode arrays, Geophys. Prospect., 52, 379398, 2004

Dikau, R.: Mass Movement, in: Encyclopedia of Geomorphology, edited by: Goudie, A., 644-652, 2004.

Hampacher, M., Jiř́kovský, T., and Koska, B.: Automated monitoring of side slopes of the ČSA open-pit mine, Czech. Tech. Univ., Prague, 19, 2008 (in Czech).

Hartvich, F. and Valenta, J.: The identification of faults using morphostructural and geophysical methods: a case study from Strašín Cave, Acta Geodyn. Geomater. 8, 425-441, 2011.

Kalvoda, J., Stemberk, J., Vilímek, V., and Zeman, A.: Analysis of levelling measurements of the Earth's surface movements on the geodynamic polygon Mikulovice-Jezeří in the Krušné hory Mts., Proc. 6th Int. IAEG Cong., 3, 1631-1637, 1990.

Klimeěs, J., Baroň, I., Pánek, T., Kosacčík, T., Burda, J., Kresta, F., and Hradecký, J.: Investigation of recent catastrophic landslides in the flysch belt of Outer Western Carpathians (Czech Republic): progress towards better hazard assessment, Nat. Hazards Earth Syst. Sci., 9, 119-128, doi:10.5194/nhess-9-119-2009, 2009.

Loke, M. H.: Least-squares deconvolution of apparent resistivity pseudosections, Geophysics, 60, 1682-1690, 1995.

Loke, M. H. and Barker, R. D.: Rapid least-squares inversion of apparent resistivity pseudosections by a quasi-Newton method, Geophys. Prospect., 44, 131-152, 1996.

Loke, M. H., Wilkinson, P. B., and Chambers, J. E.: Fast computation of optimized electrode arrays for $2 \mathrm{D}$ resistivity surveys, Comput. Geosci., 36, 1414-1426, 2010.

Malkovský, M.: Důležité zlomy platformního pokryvu severní části Českého masívu, Výzk Ústř, Úst. Geol., 14, 7-12, 1977 (in Czech).

Malkovský, M.: Geology of the North Bohemian Brown Coal Basin and its surroundings, Prague, 1985.

Marek, J.: Průzkum kvartéru v oblasti kateřinohorské klenby Krušných hor a v přilehlé části severočeské pánve, Geol. Surv., 22, 65-68, 1980a (in Czech).

Marek, J.: Štolové převedení Šramnického a Černického potoka v Krušných horách, Geol. Surv., 22, 269-271, 1980b (in Czech).

Marek, J.: Problems of the Jezeři Castle in the Krušné hory Mts., after completion of engineering-geological survey, Památ. a Přír., 8, 228-237, 1983 (in Czech).
NASA: available at: http://www2.jpl.nasa.gov/srtm, last access: 16 June 2011.

Pánek, T., Šilhán, K., Tábořík, P., Hradecký, J., Smolková, V., Lenart, J., Brázdil, R., Kašičková, L., and Pazdur, A.: Catastrophic slope failure and its origins: case of the May 2010 Girová Mountain long-runout rockslide (Czech Republic), Geomorphology, 130, 352-364, 2011.

Pichler, E.: Pevnostní a přetvárné charakteristiky nezpevněných a zpevněných jílovtých hornin, Stabilita svahů na povrchových hnědouhlených dolech, Brown Coal Res. Inst., 101-123, 1989 (in Czech).

Pichler, E. and Malá, D.: Continuous evaluation of monitoring of the side slopes of the ČSA open-pit mine and the technical supervision of the ČSA open-pit mine, Brown Coal Res. Inst., Most, 2009 (in Czech).

Pichler, E., Burda, J., and Malá, D.: Continuous evaluation of monitoring of the side slopes of the ČSA open-pit mine and the technical supervision of the ČSA open-pit mine, Brown Coal Res. Inst., Most, 2011 (in Czech).

Pletichová, M.: Hydrogeologická problematika v prostoru ochranného pilîre SKPJ, Zpravodaj Hnědé uhlí, 3, 12-16, 2006 (in Czech).

Rowlands, K. A., Jones, L. D., and Whitworth, M.: Landslide laser scanning: a new look at an old problem, Q. J. Eng. Geol. Hydrogeol., 36, 155-157, 2003.

Rybár, J.: Influence of discontinuities on the stability of slopes in the Miocene, Proc. 3rd Int. IAEG Cong., 82-87, 1978.

Rybář, J.: The engineering-geological zoning of the outcrop part of the North-Bohemia brown-coal basin at the footing of Krušné Hory Mts., Acta Montana, 77, 3-64, 1987.

Rybáŕ, J.: Interpretation of data about technogenic activity at the toe of Krušné Hory Mts. affecting endogenous and exogenous processes in the rock environment, Acta Montana, 106, 9-24, 1997.

Rybář, J.: Bedeutung der klimatischen Verhältnisse für die Aktivität von Rutschungen, Mitteilungen für Ingenieurgeologie und Geomechanik, 4, 89-104, 2001 (in German).

Rybář, J. and Novotný, J.: Impact of climatic factors on stability of natural and anthropogeneous slopes, Zpravodaj Hnědé uhlí, 3, 13-28, 2005 (in Czech).

Schrott, L. and Sass, O.: Application of field geophysics in geomorphology: advances and limitations exemplified by case studies, Geomorphology, 93, 55-73, 2008.

Schuster, R. L. and Wieczorek, G. F.: Landslide triggers and types, in: Landslides, edited by: Rybáŕ, J., Stemberk, J., and Wagner, P., London, 59-79, 2002.

Stark, T. D. and Eid, H. T.: Slope stability analyses in stiff fissured clays, J. Geotech. Geoenvironmental Eng., 123, 335-343, 1997.

Škvor, V.: Geologie české části Krušných hor a Smrčin, Prague, 1975 (in Czech).

Špůrek, M.: Sesuvné jevy u Dřinova na Mostecku, Věst. Ustř. Úst. Geol., 49, 231-234, 1974 (in Czech).

Štroner, M. and Pospíšil, J.: Terestrické skenovací systémy, Czech. Tech. Univ., Prague, 2008 (in Czech).

Váně, M.: Sutě a sesuvy na úpatí Krušných hor, Čas. Min. Geol., 5, 174-177, 1960 (in Czech).

Váně, M.: The geological structure of the Krušné hory-piedmont graben and its tectogesis, Sbor. Geol. Věd, 40, 147-181, 1985 (in Czech). 
Wack, R. and Stelzel, H.: Laser DTM generation for South-Tyrol and 3D-visualization, 2005.

Zmítko, J.: Fosilní sesuvy při podkrušnohorském výchozu pánve, Hnědé uhlí, 6, 12-24, 1983 (in Czech).
Žižka, L. and Halîr, J.: Geological model of the Quaternary sediments, Model CARE, 583-585, 2009.

Žižka, L. and Halîr, J.: Hydrogeological circumstances of the Quaternary cover in the Central part of the Most Basin, Model CARE, 583-585, 2010. 